\title{
Intervention Social Support on Patients of CA. Cervix at Vina Estetika Hospital Medan
}

\author{
Namora Lumongga Lubis ${ }^{1 *}$ and Hasnida Hasan ${ }^{2}$ \\ ${ }^{1}$ Department of Public Health, University of North Sumatera, Medan, North Sumatera, Indonesia \\ ${ }^{2}$ Department of Psychology, University of North Sumatera, Medan, North Sumatera, Indonesia
}

\begin{abstract}
This research aims to identify the effect of Social Support (SS) intervention on the increase in the level of self-esteem and a decrease in the level of depression among cancer patients in Medan, Indonesia. The research that carried out is quantitative study. The quantitative study is applied to know the self-esteem scoring by SelfEsteem Rosenberg scale (RSE) and to know the depression score using Beck Depression Inventory scale (BDI). A quantitative analysis uses to know the interaction between intervention toward self-esteem and depression in groups. The groups consist of two groups: 10 people in SS group and eight people in Control group. T-test dependent results showed that the Self Esteem Rosenberg scale (RSE), on average, post-test score show greater self-esteem than pre-test score. Negative $t$ value indicates that the average self-esteem of participants is lower than their self-esteem after obtaining social support interventions. This study shows that social support interventions significantly influence cancer patients to improve self-esteem and lower levels of depression. Although both have a significant influence to cancer patients, it turns out in this study social support interventions are much more effective in reducing levels of depression than by raising the self-esteem of participants.
\end{abstract}

\section{Keywords: Cancer; Depression; Self-esteem; Social support}

\section{Introduction}

This decade, non-communicable diseases such as cancer become a global burden with an ever-increasing mortality rate every year. According to WHO cancer incidence increased from 12.7 million cases in 2008 to 14.1 million cases in 2012. Meanwhile the number of deaths increased from 7.6 million people in 2008 to 8.2 million in 2012. Cancer is the main cause of death in the world. It is estimated that by 2030 , cancer incidence can reach 26 million people and 17 million people died from cancer, especially for poor and developing countries it will happen sooner.

In Indonesia, the prevalence of cancer is also quite high. Based on data from the Health Research, the prevalence of cancer in Indonesia is 1.4 per 1000 population, or about 330,000 people. Indonesia's highest cancer in women is breast cancer and cervical cancer (ca.cervix). It is estimated that the annual cancer cases in Indonesia will increase from 14 million in 2012 to 22 million in the next decade. Approximately 330,000 people and the highest in Indonesia cancer in women with breast cancer and cancer Ca.Cervix.

In North Sumatra, Ca. Cervix main ranks around 4,694 people (0.7\%), followed by breast cancer $2682(0.4 \%)$. Based on data from the Hospital Information System 2010, inpatient cases 12,014 cases of breast cancer (28.7\%), 5,349 cases of cervical cancer $(12.8 \%)$. The prevalence of cancer indicates that the cancer is the leading cause of death and the number is increasing. One of the diseases are dangerous and deadly cancer is Ca. Cervix is a malignancy that occurs in Ca.Cervix that is an area in which the female reproductive organ is the entrance to the uterus located between the womb and the vagina.

Most patients Ca. Cervix not only physical discomfort but also experience psychological disorders such as stress and anxiety. It became the cause of depression in patients is characterized by the emergence of symptoms of psychological, physical, social and distinctive, like sadness prolonged, sensitive, irritable, irritability, loss of confidence, loss of concentration, low self, and immune deficiencies [1].

The level of stress that leads to depression a patient Ca.Cervix accelerate the growth of cancer cells in the body, thereby aggravating the health condition. The onset of depression in cancer patients led to the worsening state of the patient. Currently, an estimated $25 \%$ of cancer patients experience depression, $66 \%$ of cancer patients with anxiety, and $85 \%$ of cancer patients with depression and anxiety [2] Under these conditions, it would require a social support interventions to improve patient understanding and skills Ca.Cervix. The social support interventions aimed at empowering potential, cope with stress, controlling the level of depression, recognize cognitive impairment, change how you think, and increase the confidence of patients $\mathrm{Ca}$. Cervix. Therefore, patients Ca.Cervix not only treated medically in the form of drugs, but also by social support interventions. This makes doctors who treat patients Ca.Cervix shall also pay attention to psychological and social aspects of the patient in order to speed the healing Ca.Cervix

Social support is one of the important factors in combating stress and determine the person's reaction or response in the face of stress [3]. Cohen and Wills defines social support as an aid or aid received by a person of their interactions with others. Social support is important in reducing the adverse effects and the effect of stress on the process of coping. Social support is a social factor that comes from outside the individual that can improve an individual's ability to cope with stressors.

Social support is also defined as a feeling of comfort, respect, attention, concern and help received from others. Social support also

*Corresponding author: Namora Lumongga Lubis, Department of Public Health, University of North Sumatera Medan, North Sumatera, 2015 Indonesia Tel: +62-813-7683-1070; E-mail: zafarpohan4@gmail.com

Received February 16, 2018; Accepted April 05, 2018; Published April 07, 2018

Citation: Lubis NL, Hasan H (2018) Intervention Social Support on Patients of CA. Cervix at Vina Estetika Hospital Medan. J Cancer Sci Ther 10: 076-079. doi: 10.4172/1948-5956.1000522

Copyright: () 2018 Lubis NL, et al. This is an open-access article distributed under the terms of the Creative Commons Attribution License, which permits unrestricted use, distribution, and reproduction in any medium, provided the original author and source are credited. 
Citation: Lubis NL, Hasan H (2018) Intervention Social Support on Patients of CA. Cervix at Vina Estetika Hospital Medan. J Cancer Sci Ther 10: 076-079. doi: 10.4172/1948-5956.1000522

affects screening behaviours [1,4-6]. Social support also has been shown to protect health [3]. Emotional/informational support and positive social interaction have been shown to be associated with annual mammograms screening [5] and emotional support [4] and positive social interaction [7].

Based on the objectives to be achieved, the authors wanted to intervene in cancer patients CA.Cervix, Medan, using psychological treatment in the form of social support interventions.

\section{Materials and Methods}

The method used in this research is quasi experiment with using the scale of The Beck Depression Inventory (BDI) to measure the level of depression and the Rosenberg Self-Esteem scale (RSE) to measure self-esteem of cancer patients. This study design uses two group protest post-test design. The participants in this study are 20 patients with cancer in Pirngadi RSU and the RSU Adam Malik. The sample was divided into two parts namely the eight participants in the control group (untreated) derived from RSU Pirngadi and 12 participants in the experimental group (treated / intervention) comes from the Adam Malik Hospital.

Samples were selected based on Arikunto formula in amount of $20 \%$, where the conditions laid down which is the total population of more than 100 people have qualified. Thus, based on the formula:

$$
n=\frac{20}{100} \times 100=20
$$

Results obtained for 20 CA. Cervix patients in total. Samples were divided by two sections; 8 (eight) participants as the control group (didn't get treatment) came from RSU Pirngadi Medan, and 12 (twelve) participants as the experiment group (got treatment/interventions) came from RSU Adam Malik Medan.

\section{Result and Discussion}

\section{Respondent characteristics distribution}

Age of participants varied from 36 years to 51 years. An average age of control group was 42 years and average age of experimental group was 46 years. Education of participantsaried from senior high school to under graduate. Majority were senior high school. All study participants were married (Table 1).

Variable frequency distribution: Table 2 showed that on pre-test condition, largely self-esteem scores of the participants were at low levels. The mean $(M=13.38)$ of the control group washigher than the mean $(\mathrm{M}=12.83)$ the experimental group.

Table 3 showed that on pre-test condition, largely depression

\begin{tabular}{|c|c|c|}
\hline \multicolumn{1}{|c|}{ Age (years) } & N & \% \\
\hline $35-39$ & 1 & 5 \\
\hline $40-44$ & 9 & 45 \\
\hline $45-49$ & 8 & 40 \\
\hline $50-54$ & 2 & 10 \\
\hline Total & 20 & 100 \\
\hline Education & \multicolumn{1}{|c|}{} \\
\hline Senior High School & 13 & 65 \\
\hline Graduate Diploma 1 & 4 & 20 \\
\hline Bachelor & 3 & 15 \\
\hline Total & 20 & 100 \\
\hline
\end{tabular}

Table 1: Respondent characteristic distribution.

\begin{tabular}{|c|c|c|c|}
\hline Level & Control Group (\%) & Experimental Group (\%) & Total \\
\hline Low & $6(30 \%)$ & $10(50 \%)$ & $16(80 \%)$ \\
\hline Normal & $2(10 \%)$ & $2(10 \%)$ & $4(20 \%)$ \\
\hline Total & $8(40 \%)$ & $12(60 \%)$ & $20(100 \%)$ \\
\hline
\end{tabular}

Table 2: Level of self-esteem on pre-test condition.

\begin{tabular}{|c|c|c|c|}
\hline Level & Control Group (\%) & Experimental Group (\%) & Total \\
\hline Normal & -- & - & 0 \\
\hline $\begin{array}{c}\text { Mild mood } \\
\text { disturbance }\end{array}$ & -- & -- & 0 \\
\hline $\begin{array}{c}\text { Borderline } \\
\text { Clinical derepssion }\end{array}$ & -- & -- & 0 \\
\hline Severe depression & $3(15 \%)$ & $3(15 \%)$ & $6(30 \%)$ \\
\hline $\begin{array}{c}\text { Extreem } \\
\text { depression }\end{array}$ & $5(25 \%)$ & $9(45 \%)$ & $14(70 \%)$ \\
\hline Total & $8(40 \%)$ & $12(60 \%)$ & $20(100 \%)$ \\
\hline
\end{tabular}

Table 3: Level of depression on pre-test condition.

\begin{tabular}{|c|c|c|c|}
\hline Level & Control Group (\%) & Experimental Group (\%) & Total \\
\hline Low & $7(35 \%)$ & -- & $7(35 \%)$ \\
\hline Normal & $1(5 \%)$ & $12(60 \%)$ & $13(65 \%)$ \\
\hline Total & $8(40 \%)$ & $12(60 \%)$ & $20(100 \%)$ \\
\hline
\end{tabular}

Table 4: Level of self-esteem on prost-test condition.

\begin{tabular}{|c|c|c|c|}
\hline Level & Control Group (\%) & Experimental Group (\%) & Total \\
\hline Normal & -- & $3(15 \%)$ & $3(13 \%)$ \\
\hline $\begin{array}{c}\text { Mild mood } \\
\text { disturbance }\end{array}$ & -- & $7(35 \%)$ & $7(35 \%)$ \\
\hline $\begin{array}{c}\text { Borderline } \\
\text { Clinical derepssion }\end{array}$ & -- & $2(10 \%)$ & $2(10 \%)$ \\
\hline $\begin{array}{c}\text { Severe depression } \\
\text { Extreem } \\
\text { depression }\end{array}$ & $3(15 \%)$ & -- & $3(15 \%)$ \\
\hline Total & $5(25 \%)$ & -- & $5(25 \%)$ \\
\hline
\end{tabular}

Table 5: Level of depression on post-test condition.

\begin{tabular}{|c|c|c|c|c|}
\hline Test & N & Mean & Std. Deviation & Std. Error Mean \\
$\begin{array}{c}\text { Pre-Test } \\
\text { RSE.KK }\end{array}$ & 8 & 13.38 & 1.768 & 0.625 \\
\hline $\begin{array}{c}\text { Pre-Test } \\
\text { RSE.KE }\end{array}$ & 12 & 12.83 & 2.167 & 0.626 \\
\hline
\end{tabular}

Table 6: One-sample statistics.

scores of the participants were at severe depression and extreem depression levels. The mean $(\mathrm{M}=30.88)$ of the control group mean was lower than the mean $(\mathrm{M}=35.42)$ of the experimental group. Referring to the norm in the BDI scale, the control group had levels of depression tend toward severe category, while the experimental group had a severe level of depression in the category associated with ca.cervix illnesses they suffered.

Table 4 showed generally level of self-esteem in the control groups were at low levels both during the pre-test and post-test. In fact, one participant at the time of the post-test scores of self-esteem is concerned decreased from normal levels become low levels. In the experimental group, there was a change in score between pre-test and post-test. All participants experienced an increase in self-esteem score when done post testand all were at normal levels of self-esteem.

Table 5 showed that all participants of the control group did not experience changes in their levels of depression. The Level of depression were severe on pre-test and post test. In the experimental group, there was a change in score between pre-test and post-test. All participants experienced a decrease in depression scores when performed after test. 
Citation: Lubis NL, Hasan H (2018) Intervention Social Support on Patients of CA. Cervix at Vina Estetika Hospital Medan. J Cancer Sci Ther 10: 076-079. doi: 10.4172/1948-5956.1000522

\begin{tabular}{|c|c|c|c|c|c|c|}
\hline \multicolumn{5}{|c|}{ Test Value $=0$} & \multicolumn{2}{|c|}{$95 \%$ Confidence Interval of the Difference } \\
\hline Test & $\mathbf{t}$ & df & Sig. (2-tailed) & Mean Difference & Lower & Upper \\
\hline Pre-Test RSE.KK & 21.4 & 7 & 0 & 13.375 & 11.9 & 14.85 \\
\hline Pre-Test RSE.KE & 20.513 & 11 & 0 & 12.833 & 11.46 & 14.21 \\
\hline
\end{tabular}

\begin{tabular}{|c|c|c|c|c|c|c|c|}
\hline \multirow{3}{*}{$\begin{array}{l}\text { Education } \\
\text { High School }\end{array}$} & \multirow{3}{*}{\begin{tabular}{|c|} 
Age \\
$35-39$ \\
\end{tabular}} & \multirow{3}{*}{$\begin{array}{l}\text { Group } \\
\text { Control }\end{array}$} & \multirow{2}{*}{\multicolumn{2}{|c|}{ RSE Level }} & \multicolumn{2}{|c|}{ BDI Level } & \multirow{3}{*}{$\begin{array}{c}\text { Total } \\
1 \\
\end{array}$} \\
\hline & & & & & \multirow{2}{*}{$\begin{array}{c}\text { Moderate Depression } \\
-\end{array}$} & \multirow{2}{*}{$\begin{array}{c}\text { High Depression } \\
1\end{array}$} & \\
\hline & & & RSE Level & Low & & & \\
\hline & \multirow{6}{*}{$40-44$} & \multirow{4}{*}{ Control } & Total & - & - & 1 & 1 \\
\hline & & & \multirow{2}{*}{ RSE Level } & Low & 1 & 1 & 2 \\
\hline & & & & Normal & 1 & 0 & 1 \\
\hline & & & Total & - & 2 & 1 & 3 \\
\hline & & \multirow{2}{*}{ Experiment } & RSE Level & Low & 1 & 2 & 3 \\
\hline & & & Total & - & 1 & 2 & 3 \\
\hline & \multirow{5}{*}{$45-49$} & Control & RSE Level & Low & & 2 & 2 \\
\hline & & & Total & - & & 2 & 2 \\
\hline & & \multirow{2}{*}{ Experiment } & RSE Level & Low & & 2 & 2 \\
\hline & & & - & Normal & & 1 & 1 \\
\hline & & \multicolumn{2}{|c|}{ Total } & - & & 3 & 3 \\
\hline & \multirow{2}{*}{$50-54$} & \multirow{2}{*}{ Experiment } & RSE Level & Low & & 1 & 1 \\
\hline & & & Total & - & & 1 & 1 \\
\hline \multirow{7}{*}{ Diploma 1} & $40-44$ & Control & RSE Level & Normal & & 1 & 1 \\
\hline & & & Total & - & & 1 & 1 \\
\hline & $15-49$ & Fyneriment & RSE Level & Low & & 1 & 1 \\
\hline & $40-45$ & гхреппиен & - & Normal & & 1 & 1 \\
\hline & & & Total & - & & 2 & 2 \\
\hline & $50-54$ & Fxperiment & RSE Level & Low & & 1 & 1 \\
\hline & & & Total & - & & 1 & 1 \\
\hline & $40-44$ & Control & RSE Level & Normal & 1 & & 1 \\
\hline & $4 U-44$ & COIIIUI & Total & - & 1 & & 1 \\
\hline S1 & $40-44$ & Fyneriment & RSE Level & Normal & 1 & & 1 \\
\hline 19 & $40-44$ & гxpentment & Total & - & 1 & & 1 \\
\hline & $45-49$ & Experiment & RSE Level & Normal & 1 & & 1 \\
\hline & $45-49$ & ехреппиель & Total & - & 1 & & 1 \\
\hline
\end{tabular}

Table 8: Pre-test level RSE and BDI research participants based on education and age.

Experimental group participants who had severe depression levels decreased to limit the depression phase, participants who are in the stage of depression is decreased to mood disorders and participants as a pre-test at the stage of mood disorders decreased to normal at the time of the post-test (Tables 6 and 7).

Based on paired t-test, it appears that for the variable self-esteem, the mean post-test $(\mathrm{M}=14.95)$ was higher than the mean pre-test $(\mathrm{M}=13.05)$. Correlation esteem between before and after the given social support is $r=0.058$ with a significance value of 0808 . There are differences in mean $=-1.900$, the value of the experimental group before to after the intervention given social support. T (19)=- 3,226 and $\mathrm{p} 0.004<0: 01$ show a very significant difference that the value of self-esteem after receiving the intervention is higher than the value of self-esteem before getting intervention. The impact of social support interventions to improve self-esteem in the experimental group can be seen from the value of $r=0.595$ by $\mathrm{r}^{2}=0.354$.

In the depression variables, the mean post-test $(M=20.05)$ is smaller than the mean pre-test $(\mathrm{M}=35.05)$. Correlation between the level of depression before and after the given social support is $r=-0.115$ with significant value 0.629 . There are differences in mean $=15.000$ the experimental group before and after the depression value given social support interventions. $T(19)=6.052$ and $\mathrm{p} 0.000<0.01$, show a very significant difference that the value of depression after receiving the intervention is lower than the value of the depression before it gets intervention. The impact of social support interventions in reducing depression in the experimental group can be seen from the value $r=11.088$, by $\mathrm{r}^{2}=0.658$.

\section{Socio-demography analysist}

Based on RSE scale pretest results, there were 7 (seven) control group participants at a low level and one participant was at a normal level. It means, seven participants had a low self-esteem and only one participant had a normal self-confidence to CA. Cervix they suffer.

As can see from the mean of the two groups, the mean of control group 13.38 is greater than the mean of 12.83 experimental groups. Referring to norms on the RSE scale, both of the control group and the experimental group have low self-esteem associated with the CA. Cervix they had suffer.

Based on socio-demography results in Table 8 , mostly the control group's self-esteem level were at the low level both during pre-test and post-test. Even there was a participant from control group during the post-test the self-esteem score were decreasing from normal to lowlevel. In the experimental group, there was a change of score between pre-test and post-test. All the participants experienced an increase in self-esteem score during the post-test and everyone were at a normallevel self-esteem (Tables 9 and 10). 
Citation: Lubis NL, Hasan H (2018) Intervention Social Support on Patients of CA. Cervix at Vina Estetika Hospital Medan. J Cancer Sci Ther 10: 076-079. doi: 10.4172/1948-5956.1000522

\begin{tabular}{|c|c|c|c|c|}
\hline \multicolumn{1}{|c|}{} & N & Mean & Std. Deviation \\
\hline Pest & 8 & 30.88 & 6.686 \\
\hline Pre-Test BDI.KK & 12 & 35.42 & 2.364 \\
\hline
\end{tabular}

Table 9: One-sample statistics.

\begin{tabular}{|c|c|c|c|c|c|c|}
\hline \multicolumn{9}{|c|}{ Test Value=0 } & \multicolumn{2}{c|}{ 95\% Confidence Interval of the Difference } \\
\hline Test & $\mathbf{t}$ & $\mathbf{d f}$ & Sig. (2-tailed) & Mean Difference & Lower \\
\hline Pre-Test BDI.KK & 13.062 & 7 & 0 & 30.875 & 25.29 \\
\hline Pre-Test BDI.KE & 29.296 & 11 & 0 & 35.417 & 36.46 \\
\hline
\end{tabular}

Table 10: One-sample test.

Based on BDI scale pre-test result, there was three participants of control group at the moderate-level depression and five participants at the high-level depression related to CA. Cervix they suffered. If viewed from the mean of the two groups, the control group mean 30.88 is lower than the mean of 35.42 experimental group. Referring to norms on BDI scale, the control group had moderate to severe category depression while the experimental group had a severe level of depression associated with the CA Cervix disease they suffered.

\section{Conclusion}

1. Social support intervention succeeded in improving self-esteem and lower levels of depression in the experimental group.

2. There is a correlation between self-esteem before and after a given social support. However, the correlation to increasing self-esteem in the experimental groupwas smaller. The correlation is not significant enough to explain the relationship of social support to increase self-esteem. Social support interventions contributed $35.4 \%$ in the experimental group improved self-esteem, while $64.6 \%$ is determined by other factors.

3. There is correlation between the level of depression before and after the given social support. The intervention provided to correlate large enough to lower the rate of depression in the experimental group and shows the correlation is significant enough to explain the relationship of social support interventions for depression.

4. The impact of social support interventions in reducing depression in the experimental group can be seen from contributed $65.8 \%$ in the experimental group decreased depression while $34.2 \%$ is determined by other factors.

\section{Suggestion}

For further research, to see the impact of social support interventions the various types of cancer patients can be considered. Rarely do research related to interven-sion in male cancer patiens. They also were ralely can be considered to see the impact of social support interventions.

\section{jA}

1. Allen JD, Stoddard AM, Sorensen G (2008) Do social network characteristics predict mammography screening practices? Health Educ Behav 35: 763-776.

2. Bintang YA, Ibrahim K, Emaliyawati E (2012) Gambaran kecemas, stress and depressors can be used in the kemer menjalani kemoterapi in salty RS in Kota Bandung.

3. Cohen S, Lemay EP (2007) Why would social networks be linked to affect and health practices? Health Psychol 26: 410-417.

4. Gamara CJ, Paz EP, Griep RH (2009) Social support and cervical and breast cancer screening in Argentinean women from a rural population. Public Health Nurs 26: 269-276.

5. Messina CR, Lane DS, Glanz K, West DS, Taylor V, et al. (2004) Relationship of social support and social burden to repeated breast cancer screening in the women's health initiative. Health Psychol 23: 582-594.

6. Riskesdas (2013) Presentation Principles of Basic Health Research Results.

7. Silvia IT, Griep RH, Rotenberg L (2009) Social support and cervical and breast cancer screening practices among nurses. Rev Lat Am Enfermagem 17: 514-521. 